\title{
Continuing Education in Italy: A Case Study
}

\author{
Sha $\mathrm{Ha}^{1}$ \\ ${ }^{1} \mathrm{PhD}$, Ca' Foscari Venice University, School of Foreign Studies, Guangzhou University, P.R. China \\ Correspondence: Dr. Sha Ha, School of Foreign Studies, Guangzhou University, P.R. China
}

Received: July 14, 2018

Accepted: August 25, 2018

Online Published: September 17, 2018

doi:10.5430/ijhe.v7n5p29

URL: https://doi.org/10.5430/ijhe.v7n5p29

\begin{abstract}
According to the 'International Standard Classification of Education' (ISCED), 'Continuing Education' is composed of the 'Continuing Primary and Lower Secondary Adult Education' (ISCED1, ISCED2), followed by the 'Adult Education and Training' System (ISCED3), including an 'Upper Secondary Education System' (ISCED4 and finally, the 'Tertiary Education' (ISCED5, ISCED6 and above). In 2016 the percent of 'early leavers' from education and training amounted in Italy to $13.8 \%$, while the EU average amounted to $10.7 \%$. In the same period the attendance to ISCED1-ISCED3 Adult Education Courses (age 25-64) amounted to 8.3\%, while the EU average amounted to $10.8 \%$. As for 'Tertiary Education', the percent attainment of a university degree amounted to $29.5 \%$ among Italians and to $13.4 \%$ among foreigners residing in Italy, while the EU averages amounted to $39.9 \%$ and $35.4 \%$ respectively. According to the Author, the relatively higher percent of early leavers from education and training in Italy and the relatively low attendance to 'Continuing Education' programs is due to the low employment rate in the Country, particularly significant in the age range 20-34, as a consequence of the severe economic crisis which hit the country in 2008 and still persists, causing the closure of many private enterprises and the block of the turn-over at public educational institutions. In spite of all that, the quality of the Italian Primary, Secondary and Tertiary Education System is of an excellent level, as compared with that of similar institutions all over the world. In Author's opinion, increasing the investment in the educational system would increase the attendance to Secondary and Tertiary Adult Education courses, with a positive feedback on productivity.
\end{abstract}

Keywords: primary and secondary adult education, adult education and training, upper secondary education, undergraduate and postgraduate tertiary education

\section{Introduction}

Since the starting of the Bologna Process in 1999, the member states of the European Union (EU) have been actively working on the definition of a common educational policy. Continuing Education constitutes an important chapter of this joint effort (Pavan, 2010; Milana \& Holford, 2014), which involves not only the Primary, Secondary and Upper Secondary Education, but also the Tertiary Education (subdivided into Undergraduate and Postgraduate University Education). Purpose of this research is to examine the present state of the Italian Continuing Education System, the University System included. As for the Primary and Secondary Continuing Education, the adopted methodology consisted of examining the laws and the official reports from the Italian Ministry of Education and the official reports of the European Commission (such as EUROSTAT and the yearly edition of the Education and Training Monitor from 2012 to 2018) as well as books and research papers by educationalists, such as the volume entitled 'Adult Education Policy and the European Union', edited in 2014 by Milana F. and Holford J. As for the Tertiary Education, the Author adopted as a case study the University of Padua $(U P)$, one of the Italian higher education institutions of excellence (Ha, 2018a). The extremely kind cooperation by the academic staff and the Statistical Office allowed the Author to obtain an updated information about the educational system of UP university, what constitutes the added value of the present research. Its limits lie in the fact that UP is only one, although a significant one, of the 68 Italian public universities. The present paper is subdivided into Section 1 (Introduction), Section 2 (Primary, Secondary and Upper Secondary Adult Education and Training in Italy), Section 3 (The University of Padua and its Tertiary Education System) and Section 4 (Conclusions). A Section of References and an Appendix complete the text: the latter is subdivided into Section A1 (Undergraduate Education at UP), Section A2 (Postgraduate Education at UP) and Section A3 (International Higher Education Institutions cooperating with UP). 


\section{Primary, Secondary and Upper Secondary Adult Education and Training in Italy}

Following the EU recommendations, the Italian Ministry of Education enacted in 2010 a Primary and Secondary School Reform and, one year later, a University Reform (Ministero dell'Istruzione, dell'Università e della Ricerca, 2010, 2011), with the purpose of adapting the Italian education system to the EU requirements. After those two reforms, the Italian government enacted in 2012 a law entitled 'Provisions on the reform of the labor market in a growth perspective' (Disposizioni in materia di riforma del mercato del lavoro in una prospettiva di crescita), foreseeing the creation of a Territorial Network for Primary and Secondary Adult Education (Centri Provinciali di Istruzione per Adulti, CPIA), open to Italians and foreigners residing in the country. To that network belong public schools and educational institutions from the private sector, while the funds for those activities constitute the Joint Committee Inter-professional Funds: they originate from multiple sources (Governmental and Regional Funds, European Social Funds and also private funds financed by the Italian Union of Industrialists). Additional funds are offered by single industrial enterprises, trade associations of the Italian Chambers of Commerce, professional associations and worker unions. A new school reform, known as 'La Buona Scuola' (The Good School), was enacted in 2015, 'to regulate the autonomy of educational institutions by equipping them with the human, material and financial resources, as well as the flexibility needed to implement their training and organizational choices' (Ministero dell'Istruzione, dell'Università e della Ricerca, 2015). This last reform foresaw the introduction of a three-year planning of the training offer, where the schools indicate the needs of the teaching, administrative, technical and auxiliary staff. The objectives of the reform are, among others, the enhancement of foreign languages' teaching and the strengthening of mathematical, logical and scientific skills.

According to the International Standard Classification of Education (ISCED), the Italian Primary School System (ISCED1) consists of 5-grades Elementary Schools, followed by a 3-grades Lower Secondary School System (ISCED2), a 5-grades Higher Secondary School System (ISCED3) and an Upper Secondary Education System: the latter is constituted of 3-grade courses at Higher Technical Institutes (Istituti Tecnici Superiori, ITS) (ISCED4). The Italian compulsory education starts at 6 years of age and lasts for 10 years. All study cycles (the Primary, the Lower Secondary, the Higher Secondary and the Upper Secondary ones) end with a State Exam. The transition from the Elementary School to Lower Secondary School, as well as from Lower Secondary School to Higher Secondary School and from Higher Secondary School to the Upper Secondary one or to University require passing a State Exam. The access to Higher Technical Institutes (ISCED4) or to University (ISCED5) are subject to passing a subsequent Admission Exam. The Primary and Lower Secondary Adult Education are organized by Centers for Basic Educational Training and the courses are taught at Elementary Schools or Junior High Schools. After attending the courses and passing the related exams, the participants obtain a Certification of Basic Education.

The Higher Secondary Adult Education and Training is organized by Centers for Vocational Education, where evening courses are taught at regional Vocational Institutes (Istituti Tecnici or Istituti Professionali). After attending the courses and passing the related exams, the participants obtain a Diploma of Technical, Professional or Artistic Education accompanied, in case of foreign participants, by a Level 2 Certificate of Linguistic Proficiency in Italian.

As for the Upper Secondary Education, the Upper Technical Institutes (Istituti Tecnici Superiori, ITS) were established all over Italy in 2008 (D.P.C.M., 2008) and their structure was partially modified in 2011 (Ministero dell'Istruzione, dell'Università e della Ricerca, 2011). According to the Law, the ITS are 'non university institutions of specialized technical education, integrating school learning, training and working activity'. They are financed by Provinces, Regions or private enterprises and are open to a limited number of students who passed a State Exam at Secondary Education Institutes and also a specific ITS Admission Test. At the end of a biennial or triennial study program a candidate who passes the final exam becomes a certified 'Higher Technician', a degree corresponding to the $5^{\text {th }}$ Level of the EU Professional Qualifications Scheme. The ITS Technological Areas are the following:

- Energetic Efficiency,

- Sustainable Mobility,

- New Life Technologies,

- New Technologies for the 'Made in Italy' (subdivided into 'Business Support Services', 'Agri-food Systems', 'House Services', 'Mechanics', 'Fashion'),

- Innovative Technologies for the Preservation of the Cultural Heritage and Tourism,

- Information and Communication Technologies, 
with a total number of 380 specialization sectors. The ITS are distributed over Italy as follows:

- North-Western Italy (Liguria, Lombardia, Piemonte): 29 units,

- North-Eastern Italy (Friuli, Veneto): 11 units,

- Central Italy (Abruzzo, Emilia, Toscana, Marche, Umbria) : 31 units,

- Southern Italy (Calabria, Campania, Puglia): 14 units,

- Sicily: 5 units,

- Sardinia: 3 units.

According to the Education and Training Monitor (European Commission, 2013), during the school year 2011/12 over 71,000 Italian and foreign adults attended the courses of Primary and Lower Secondary Education (OECD1, OECD2) while about 68,000 people attended the courses of Higher Secondary Education (OECD3) In the same period the total population permanently resident in Italy amounted to over 55,800,000 people and that of foreigners amounted to over $4,380,000$ people. The number of Italians with a diploma of $1^{\text {st }}$ grade amounted to $16,706,879$ people $(29.9 \%)$ and that of those with a diploma of Higher Secondary Education amounted to 13,706,879 (24.5\%). About $5.7 \%$ of Italian population in the age range 25-64 attended the Adult Education and Training courses of $1^{\text {st }}$ or $2^{\text {nd }}$ Level, while the proportion of foreign citizen resident in Italy who attended the Adult Education and Training courses amounted to $3.4 \%$. In the same period the EU weighted average proportion of attendances amounted to $9.2 \%$. The attendance to the courses of Adult education and training slightly increased over the years, reaching in 2017 the $8.3 \%$, while the EU average proportion for that year amounted to $10.8 \%$ (European Commission, 2017).

As for the Upper Secondary Education, according to the National Institute of Documentation, Innovation, Educational Research (Istituto Nazionale di Documentazione, Innovazione, Ricerca Educativa) (I.N.D.I.R.E., 2017), the total number of ITS in 2017 amounted to 93 units, with 8,232 students and 6216 already certified Higher Technicians (corresponding to $74.8 \%$ of the total number of participants to the final exam). As for the working position of the 1767 ITS students who graduated in 2015, a study published by I.N.D.I.R.E (2017) gave the following results: about $27.9 \%$ of them got a permanent working contract, $38.3 \%$ got a temporary working contract, $12.9 \%$ were in apprenticeship,17,6 \% were still unemployed and 3.7\% registered to University (European Commission, 2017). In 2013 the percent value of Early leavers from education and training (age 18-24) amounted in Italy to $16.8 \%$ and to $13.8 \%$ in 2016, while the corresponding EU averages were 11.9\% in 2013 and $10.7 \%$ in 2016. While the proportion of attainment of Primary and Lower Secondary Education among Italians is in line with the average European values, the relatively low participation to Secondary Continuing Education and Training courses, as compared with the corresponding EU values, can be explained with the low levels of employment in Italy in the period 2011-2016, as a consequence of the economic crisis that struck Italy and the Southern European Countries in 2008, whose effects still persist. A confirmation of that is offered by the proportion of 'Not in Employment, Education, or Training' (NEET)' people in the age range 15-24 in Italy, which in 2016 reached 19.9\%, while the EU average amounted to $14.2 \%$.

Before concluding this Section, let us quote disconcerting data concerning the average proficiency levels in Mathematics, Science and Reading (Italian texts) among students attending Italian Secondary Schools (Education and Training Monitor, 2017): the percent values of 15-year old people with underachievement in Reading amounted in 2013 to $19.5 \%, 24.7 \%$ in Mathematics and $18.7 \%$ in Science, while the corresponding EU average values amounted to $17.8 \%$ in Reading, 22.1\% in Mathematics and $16.6 \%$ in Science. In 2016 those percent rates went up to $21.0 \%$ in Reading, 23.3\% in Mathematics and $23.2 \%$ in Science, while the EU weighted average values amounted to $19.7 \%$, $22.2 \%$ and $20.6 \%$ respectively. According to the European Commission (EC), this under-proficiency should be attributed, at least partially, to the increasing presence in public schools of children of foreign immigrants with a low schooling level (Education and Training Monitor, 2017). According to the Author, special teaching courses in Primary and Secondary Adult Education for Foreigners should be introduced at regional level in order to solve this problem.

\section{The University of Padua (UP) and its Tertiary Education System}

UP is the second oldest Italian university and one of the oldest of the Western world: it was established in 1222 by initiative of the Brotherhood of Teachers and Students of the town municipality (Repubblica di Padova). Between the last quarter of the $16^{\text {th }}$ century and the first half of the $17^{\text {th }}$ century this university saw the outbreak of the Scientific Revolution, through Galileo Galilei (1564 - 1642), born in Pisa and for 18 years professor of Mathematics, Physics and Astronomy at UP, Andrea Vesalio (1514 - 1564), born in Bruxelles and author of the first modern Anatomy Atlas entitled 'De humani corporis fabrica' and others (Whitehouse, 2009). 
UP is subdivided into Departments, whose list is given in Section A1 of the Appendix. Internationalization has always been an important priority for UP: with its bilateral agreements with foreign higher education institutions (see Section A3 of the Appendix), it established long-standing international co-operations in Europe, Asia, Africa, Australia, North and South America, encouraging international exchanges of students, academic and technical staff and the development of joint research programs (Ha, 2018b).

The Undergraduate and Postgraduate Courses at UP are delivered by the following Schools: School of Agriculture and Veterinary Medicine, School of Economics and Political Sciences, Law School, School of Engineering, School of Health Sciences, School of Science, School of Psychology, School of Humanities, Social Sciences and Cultural Heritage. During the Academic Year 2016/17 the teaching/research staff of UP amounted to 2,092 units (of whom 445 were Full Professors (Professori Ordinari), 887 Associate Professors (Professori Associati), 541 Researchers with tenure (Ricercatori di Ruolo) and 179 Researchers with a temporary employment contract (Ricercatori a Contratto). The total number of students amounted in the same period to 57,404 units, subdivided into Undergraduate Students (35,227), Biennial and Single Cycle Master Degree Students (18,569), Post-Master Higher Specialization Students (1,639), Doctoral Students (1,305), Lifelong Learning Students (574).

The total number of graduates from the Lower Tertiary Education System at UP during the Academic Year 2016/17 amounted to 7,592 units (of whom 333 were Foreigners), distributed as indicated in Table 1, where the Undergraduate Courses have been subdivided into the following Areas: A1 (Agricolture \& Veterinary, Environmental Sciences, Science, Engineering), A2 (Health Sciences), A3 (Law, Economics, Psychology, Humanities, Preservation of the Cultural Heritage).

Table 1. Lower Tertiary Education System (Lauree Triennali) at UP

\begin{tabular}{|c|c|c|c|}
\hline Areas & $\begin{array}{c}\text { Italian } \\
\text { graduates }\end{array}$ & $\begin{array}{l}\text { Foreign } \\
\text { graduates }\end{array}$ & Total \\
\hline$A 1$ & 2,891 & 51 & 2,942 \\
\hline$A 2$ & 1,064 & 31 & 1,095 \\
\hline$A 3$ & 3,304 & 251 & 3,555 \\
\hline
\end{tabular}

The Postgraduate Higher Education consists of the following Courses (see Section A2 of the Appendix):

- $\quad$ 1-year Master Degrees Courses of First Level (Master di 1.o Livello), to be followed after achievement of a Bachelor Degree Diploma (Diploma di Laurea Triennale),

- 2-year Master Degrees Courses (Lauree Magistrali Bienniali), to be followed after achievement of a Bachelor Degree and the passing of an admission test,

- Single-cycle Master Degrees Courses (Lauree Magistrali a Ciclo Unico), to be followed after achievement of the High School Diploma,

- 1-year Master Degrees Courses of Second Level (Master di 2.o Livello), to be followed after achievement of a 2-year Master Degree Diploma (Diploma di Laurea Magistrale),

- Higher Specialization Degree Courses (Corsi di Specializzazione),

- Doctoral Degrees (Dottorati), to be followed after achievement of a 2-year Master Degree or a Single-cycle Master Degree and after passing an admission test,

- Lifelong Training Courses (Corsi di perfezionamento e aggiornamento).

Let us examine them in greater detail:

A) 1-year Master Degrees of First Level (Master di Primo Livello)

During the Academic Year 2016/17 the total number of graduates amounted to 1,353 units (of whom 51 Foreigners), subdivided as follows: 
Table 2. 1-year Master Degrees of First Level (Master di Primo Livello) at UP

\begin{tabular}{lrrr}
\hline Areas & $\begin{array}{c}\text { Italian } \\
\text { graduates }\end{array}$ & $\begin{array}{c}\text { Foreign } \\
\text { graduates }\end{array}$ & Total \\
\hline A1 & 907 & 11 & 918 \\
A2 & 275 & 20 & 295 \\
A3 & 119 & 20 & 139 \\
\hline
\end{tabular}

An update to 2017 brought the total number of graduates to 1,017, of whom 375 Foreigners, attending the Courses of 'Bio-building and management of real estate projects in Africa', 'Integrated Management of water resources and environmental reclamation', 'Technologies for sustainable and intercultural waste management in the African countries', 'Solar energy technologies in the African countries (MATES).

B) 2-year Master Degrees Courses (Corsi di Laurea Magistrale)

The total number of graduates in 2017 amounted to 4,077 units, of whom 148 were Foreigners, distributed as follows:

Table 3. 2-year Master Degree Courses (Corsi di Laurea Magistrale) at UP

\begin{tabular}{|c|c|c|c|}
\hline Areas & $\begin{array}{c}\text { Italian } \\
\text { graduates }\end{array}$ & $\begin{array}{l}\text { Foreign } \\
\text { graduates }\end{array}$ & Total \\
\hline$A 1$ & 2,035 & 41 & 2,076 \\
\hline$A 2$ & 172 & 3 & 175 \\
\hline$A 3$ & 1,722 & 104 & 1,826 \\
\hline
\end{tabular}

C ) Single-cycle Master Degrees Courses (Master a ciclo unico)

In 2017 the total number of Biennial Master's School graduates amounted to 1,173 graduates (of whom 25 were Foreigners), distributed as shown in Tables IVa and $I V b$ :

Table 4a. Single-cycle Health Care Master Degrees Courses at UP

\begin{tabular}{lccc}
\hline Schools & $\begin{array}{c}\text { Italian } \\
\text { graduates }\end{array}$ & $\begin{array}{c}\text { Foreign } \\
\text { graduates }\end{array}$ & Total \\
\hline Medicine and Surgery & 332 & 8 & 340 \\
(6-year Course) & & 3 & 29 \\
Dentistry and Dental Prosthesis & 26 & 1 & 55 \\
(6 year Course) & & 54 & \\
Veterinary & & & \\
(5 year Course) & & & \\
\hline
\end{tabular}

Table 4b. Other 5-year Single-cycle Master Degrees Courses at UP

\begin{tabular}{|c|c|c|c|}
\hline Schools & $\begin{array}{c}\text { Italian } \\
\text { graduates }\end{array}$ & $\begin{array}{l}\text { Foreign } \\
\text { graduates }\end{array}$ & Total \\
\hline $\begin{array}{l}\text { Law, Primary Education Sciences } \\
\text { (5-year Course) }\end{array}$ & 519 & 5 & 524 \\
\hline $\begin{array}{l}\text { Construction Engineering - Architecture (5-year } \\
\text { Course) }\end{array}$ & 63 & 3 & 66 \\
\hline Pharmacy (6-year Course) & 154 & 5 & 159 \\
\hline $\begin{array}{l}\text { Chemistry and Pharmaceutical Chemistry } \\
\text { (5-year Course) }\end{array}$ & & & \\
\hline
\end{tabular}


D) 1-year Master Degrees Courses of Second Level (Master di Secondo Livello).

In 2016 the total number of 1-year Master Degree Courses of Second Level graduates amounted to 118 units (of whom 4 were Foreigners), distributed as follows:

Table 5. 1-year Master Degree Courses of Second Level (Master di Secondo Livello) at UP

\begin{tabular}{lrrr}
\hline Sectors & $\begin{array}{c}\text { Italian } \\
\text { graduates }\end{array}$ & $\begin{array}{l}\text { Foreign } \\
\text { graduates }\end{array}$ & Total \\
\hline Healthcare for Physicians \& Healthcare for & 60 & 4 & 64 \\
Non-physicians & & & \\
Scientific Innovation & 25 & 0 & 25 \\
Psychology, Social Sciences, Legal Professions & 29 & 0 & 29 \\
\hline
\end{tabular}

An update to the year 2017 brought the total number of graduates to 521 graduates, of whom 18 were Foreigners.

E) Post-master Higher Specialization Schools (Corsi di Specializzazione)

In 2016 the total number of delivered Higher Specialization Degrees amounted to 304 specialists (of whom 10 were Foreigners), subdivided as follows:

Table 6. Post-master Higher Specialization Courses (Corsi di Specializzazione) at UP

\begin{tabular}{lrrr}
\hline Specialties & $\begin{array}{c}\text { Italian } \\
\text { graduates }\end{array}$ & $\begin{array}{l}\text { Foreign } \\
\text { graduates }\end{array}$ & Total \\
\hline $\begin{array}{l}\text { Healthcare for Physicians } \\
\text { (5-years/4-years Courses) }\end{array}$ & 227 & 10 & 237 \\
$\begin{array}{l}\text { Preservation of Archaeological and } \\
\text { Historic-artistic Heritage (2-year Courses) }\end{array}$ & 19 & 0 & 19 \\
Legal Professions (2-year Courses) & \multicolumn{2}{c}{0} & \\
\hline
\end{tabular}

To those specialties, it must be added a course on 'Evaluation and Management of Chemical Risk (2-year Course)', with a total number of 28 Italian and no foreign graduates.

An update to 2017 brought the total number of specialists to 338, of whom 17 were Foreigners.

F) 3-year Doctoral Degrees (Dottorati di Ricerca)

In 2016 the total number of delivered Doctoral Degrees amounted to 442 unitss (of whom 52 were Foreigners), distributed as follows:

Table 7. 3-year Doctoral Degrees

\begin{tabular}{lrrr}
\hline Macro-areas & $\begin{array}{l}\text { Italian } \\
\text { Research } \\
\text { Doctors }\end{array}$ & $\begin{array}{l}\text { Foreign } \\
\text { Research } \\
\text { Doctors }\end{array}$ & Total \\
\hline Macro-area 1:(Mathematics, Physics \& & 128 & 24 & 152 \\
$\begin{array}{l}\text { Astronomy, Engineering, Information Sciences, } \\
\text { Earth Sciences) }\end{array}$ & & & \\
Macro-area 2 (Life Sciences) & 153 & 12 & 165 \\
Macro-area 3 (Human and Social Sciences) & 109 & 16 & 125 \\
\hline
\end{tabular}

An update to 2017 brought the total number of Research Doctors (Ph.D.) to 430 graduates, of whom 61 were Foreigners.

G) Lifelong Training Courses_(Corsi di Perfezionamento)

During the Academic year 2016/17 the total number of professionals attending the Yearly Postgraduate Professional Updating Courses amounted to 469 units (461 Italians, 8 Foreigners), distributed as follows: 
Table 8. Lifelong Training Courses

\begin{tabular}{lrrr}
\hline Sectors & $\begin{array}{c}\text { Italian } \\
\text { graduates }\end{array}$ & $\begin{array}{l}\text { Foreign } \\
\text { graduates }\end{array}$ & \multicolumn{1}{c}{ Total } \\
\hline Healthcare for Physicians & 230 & 8 & 238 \\
Industrial Engineering & 18 & 0 & 18 \\
Legal Professions, Psychology \& Social & 213 & 0 & 213 \\
Sciences,Teacher Training & & & \\
\hline
\end{tabular}

An update to 2017 brought the total number of attendees to 574, of whom 8 were Foreigners.

This detailed exposition of the state of Continuing Education at UP highlights the excellent quality of its Tertiary Education System, capable of attracting students from many parts of the world, as certified by the biennial reports of the National Agency for the Evaluation of the University System and Scientific Research (Agenzia Nazionale per la Valutazione del Sistema Universitario), composed of independent Italian and international scholars (A.N.V.U.R., 2018).

\section{Conclusions}

Starting with the Primary and Secondary Education System, the low levels of attainment of a diploma in Italy refer mainly to the population of Foreigners residing in Italy, among which the proportion of Early leavers from Education and Training amounted in 2016 to $30.0 \%$, while it amounted to $11.8 \%$ among Italians, to be compared with $9.8 \%$ of the EU average. In this regards we should recall the following remark expressed by the European Commission: 'Italian schools are at the forefront of receiving migrant children, but their full inclusion is hindered by social stratification'. As for Tertiary Education, a certain discrepancy exists between the excellence of the Italian Tertiary Education System, as evidenced by the data referring to the University of Padua (certified by the National Agency for the Evaluation of the University System and Scientific Research in 2018) and the relatively low rate of achievers of a University Diploma, which amounted in 2016 to $29.5 \%$, while the EU average amounted to $39.9 \%$. A possible reason of that should be attributed, according to the Author, to the reduced employment rate of younger people in Italy, which started with the economic crisis of 2008 and whose effects still persist. The employment rate of people in the age range $20-34$ in Italy amounted indeed to $42.4 \%$ in 2016 , while the EU average amounted to $76.9 \%$. In addition to that, the Italian government introduced in 2008 a block of turnover (up to 80\%) in public universities (Ministero dell'Economia e Della Finanza, 2008). That block had as a consequence a brain drain of Italians with a Tertiary Education Diploma, in an age range between 30 and 40 years, toward Northern European countries and North America (Nava, 2017). As for the low attendance to Adult Education and Training courses by Italians and Foreigners, it could be explained anew through the de-motivating action exerted by the lower employment rate in Italy, as compared with that of EU. Effective measures should be introduced as soon as possible by the government to support its entire Public Education System, Adult Education included All that will not be simple, but Italy already gave an outstanding example of improvement of its social standards during its post-war period of 'Reconstruction' (Ricostruzione), from 1946 to 1960. A good omen is constituted by the recent attribution of the Field Medal in Applied Mathematics to the young Italian Mathematician Alessio Figalli, who graduated at the Higher Normal University (Scuola Normale Superiore) in Pisa and later became Professor at the Federal Polytechnic of Zurich, for his outstanding contributions in the field of Optimal Transportation Theory. Many other young Italian scholars are presently working at prestigious research centers all over the world. Let us hope for the best!

\section{Acknowledgments}

The Author's deepest gratitude is due to the academic and administrative staff of UP, and in particular to Mrs. Annalisa Nadai, from the UP Statistics Office, for their precious cooperation.

\section{References}

A.N.V.U.R. (2018). Rapporto Biennale 2018. Roma, Italy. Retrieved (July 2018) from the Pdf: http://www.anvur.it/wp-content/uploads/2018/07/Sintesi_Rapporto2018_WEB.pdf

Bonacci, M. (2018). Guidance and outreach for inactive and unemployed - Italy. Cedefop ReferNet thematic perspectives series, PDF retrieved from http://libserver.cedefop.europa,eu/vetelib/2018/guidance_outreach_Italy_Cedefop_ReferNet.pdf

Cantor, L.M., Roberts, I.F. (1979). Further Education Today. Routledge \& Kegan, London. 
D.P.C.M. (2008). Linee guida per la riorganizzazione del Sistema di istruzione e formazione tecnica superiore e la costituzione degli istituti tecnici superiori. Gazzetta Ufficiale n.86 dell'11-4-2008. Istituto Poligrafico dello Sato, Roma, Italy.

European Commission. (2013-2018). Education and Training Monitor. Directorate-General for Education and Culture, Bruxelles, Belgium.

EUROSTAT Statistics Explained. (2017). Adult Learning Statistics. Pdf retrieved from eu/eurostat/statistics-explained/index.php

EUROSTAT Statistics Explained (2018). Government Expenditure on Education. Pdf retrieved from eu/eurostat/statistics-explained/index.php (March 2018)

Ha, S. (2018a). Recent Personnel Reforms of Public universities in China and in Italy: A Comparison. International Journal of Higher Education, 7(1). Toronto, Canada. https://doi.org/10.5430/ijhe.v7n1p87.

.Ha, S. (2018b). Cultural Cooperation Activities between Italian and Chinese Universities: A Case Study. International Journal of Higher Education, 7(3). Toronto, Canada. https://doi.org/10.5430/ijhe.v7n3p16.

Heilbron, J.L. (2003). The Oxford Companion to the History of Modern Science. Oxford University Press, Oxford, UK.

Holford, H., Milana, M., Spolar, V.M. (2014). Adult and Lifelong Education: the European Union, its member states and the world. International Journal of Lifelong Education, 33(3), 267-274. https://doi.org/10.1080/02601370.2014.911518

I.N.D.I.R.E. (2017). Percorsi ITIS - Monitoraggio Nazionale 2017. Pdf retrieved from http://www.indire.it/progetto/its-istituti-tecnici-superiori/

ISCED (2011). International Standard Classification and Education. Unesco Institute of Statistics, Montreal, Canada

Istituto Italiano di Statistica (ISTAT). 2018. Statistica Flash-Occupati e Disoccupati, Gennaio 2018. Pdf retrieved from http://www4.istat.it/it/archivio/210824.

Milana, M. and Holford, J. (Eds.). (2014). Adult Education Policy and the European Union - Theoretical and Methodological Perspectives. Sense Publishers, Rotterdam, The Netherlands.

Ministero dell'Economia e della Finanza. (2008). Disposizioni urgenti per il diritto allo studio, la valorizzazione del merito e la qualità del sistema universitario e della ricerca. Gazzetta Ufficiale n.263 del 10-11-2008. Istituto Poligrafico dello Sato, Roma, Italy.

Ministero dell'Istruzione, dell'Università e della Ricerca (2010). Regolamenti di riordino degli istituti professionali, degli istituti tecnici e dei licei. Gazzetta Ufficiale n. 137 del 15-6-2010. Istituto Poligrafico dello Sato, Roma, Italy.

Ministero dell'Istruzione, dell'Università e della Ricerca (2011a). Norme in materia di organizzazione delle università, di personale accademico e reclutamento, nonché delega al Governo per incentivare la qualità e l'efficienza del sistema universitario. Legge n. 240 del 30 Dicembre 2010. Gazzetta Ufficiale n. 10 del 14-01-2011. Istituto Poligrafico dello Stato, Roma, Italy.

Ministero dell'Istruzione, dell'Università e della Ricerca (2011b). Norme generali concernenti i diplomi degli Istituti Tecnici Superiori (ITS). Decreto Ministeriale del 7 Settembre 2011. Pdf retrieved from https://it.wikisource.org/wiki/D.M._7_settembre_2011_-_Istituti_Tecnici_Superiori

Ministero del Lavoro e delle Politiche Sociali. (2012). Disposizioni in materia di riforma del mercato del lavoro in una prospettiva di crescita. Legge n. 92 del 28 Giugno 2012. Gazzetta Ufficiale n. 153 del 3-7-2012, Istituto Poligrafico dello Stato, Roma, Italy.

Nava, S. (2017). La fuga dei talenti. Il Sole 24Ore, Centro Studi FdT, Milano, Italy. Pdf retrieved (June 2018) from https://fugadeitalenti.wordpress.com.

Pavan, A. (2010). Per una prospettiva politica sulla formazione. Atti del 2.o Corso di Alta Formazione per Esperti in Educazione Civica, Diritti Umani, Cittadinanza, Costituzione. Università di Padova, Padova, Italy.

Università degli studi di Padova. (2018). Rapporto Annuale del Nucleo di Valutazione di Ateneo per l'A.A.2016-17. The Pdf has been retrieved from http://www.unipd.it. 
Whitehouse, D. (2009). Renaissance Genius: Galileo Galilei \& His Legacy to Modern Science. Sterling Publishing. New York City, N.Y.). USA.

\section{A1. Undergraduate Education at UP}

\section{Appendix:}

UP is subdivided into the following Departments: Department of Agronomy, Food, Natural Resources, Animals, and the Environment, Department of Biology, Department of Animal Medicine, Production and Health, Department of Biomedical Sciences, Department of Cardiac, Thoracic and Vascular Sciences, Department of Chemical Sciences, Department of Civil, Environmental and Architectural Engineering, Department of Comparative Biomedicine and Food Science, Department of Cultural Heritage: Archaeology and History of Art, Cinema, and Music, Department of Developmental Psychology and Socialization, Department of Economics and Management, Department of General Psychology, Department of Geosciences, Department of Historical and Geographic Sciences and the Ancient World, Department of Industrial Engineering, Department of Information Engineering, Department of Land, Environment, Agriculture, and Forestry, Department of Linguistic and Literary Studies, Department of Management and Engineering, Department of Mathematics, Department of Pharmaceutical and Pharmacological Sciences, Department of Philosophy, Sociology, Education, and Applied Psychology, Department of Physics and Astronomy, Department of Political Science, Law and International Studies, Department of Private Law and Critique of Law, Department of Public, International and Community Law, Department of Statistical Sciences, Department of Surgery, Oncology and Gastroenterology, Department of Women's and Children's Health.

The Tertiary Education System at UP is subdivided as follows:

- School of Agricultural Sciences and Veterinary Medicine, which offers the following Triennial Degree Courses: 'Animal, 'Restructuring of the Territory and Protection of the Landscape', 'Sciences and Culture of Gastronomy and Catering', 'Agricultural Sciences and Technologies', 'Food Sciences and Technologies' (Scienze e tecnologie alimentari), 'Animal Sciences and Technologies' (Scienze e Tecnologie Animali), 'Viticultural and Enological Sciences and Technologies' (Scienze e tecnologie viticole ed enologiche), 'Hygienic-sanitary Safety of Food' (Sicurezza igienico-sanitaria degli alimenti), 'Forest and Environmental Technologies'(Tecnologie forestali e ambientali).

- School of Economy and Political Sciences, which offers the following Triennial Degree Courses: 'Law and Economy', 'Economy', 'Political Sciences', 'Political Sciences, International relations and Human Rights', 'Social Services'.

- Law School, which offers the following Triennial Degree Course: 'Labor Consultant'.

- School of Engineering, which offers the following Triennial Degree Courses: 'Aerospace Engineering', 'Biomedical Engineering', 'Chemical and Materials Engineering', 'Civil Engineering', 'Energy Engineering', 'Information Engineering', 'Product Innovation Engineering', Electronic Engineering, 'Management Engineering', 'Computer engineering', 'Mechatronics Engineering', 'Environment and Territory Engineering, 'Building and Territory Techniques and Management'.

- School of Health Sciences, which offers the following Triennial Degree Courses: 'Health Care', 'Dietetics', 'Professional Education', 'Physiotherapy', 'Dental care', 'Nursing', 'Speech therapy', 'Orthoptics and Ophthalmological Assistance', 'Obstetrics', 'Applied Pharmaceutical Sciences', 'Motorial Sciences', 'Audioprosthetic Techniques', 'Prevention Techniques in the Environment and in the Workplace', 'Biomedical Laboratory Techniques', 'Neuro-physio-pathology Techniques', 'Techniques of Medical Radiology', 'Techniques for Imaging and Radiotherapy', 'Techniques of the Neuro- and Psycho-motor in the Evolutive Age', 'Occupational Therapy'.

- School of Science, which offers the following Triennial Degree Courses: 'Astronomy', 'Biology', 'Chemistry', 'Computer Science', 'Environmental Sciences and Technologies', 'Geosciences', 'Industrial Chemistry, 'Mathematics', 'Molecular Biology', 'Natural Sciences', 'Optics and Optometry', 'Physics', 'Science of Materials', 'Statistics for Economy and Business', 'Statistics for Science and Technologies'.

- School of Psychology, which offers the following Triennial Degree Courses: 'Psychological Sciences', 'Psychological Sciences and Techniques', 'Psychological, Cognitive and Psycho-biological Sciences', 'Psychological Sciences of the Personality Development and Inter-personal Relations', 'Social and Work Psychological Sciences'. 
- School of Human and Social Sciences and Cultural Heritage, which offers the following Triennial Degree Courses: 'Archeology', 'Communication Theory', 'Disciplines of the Arts, Music and Entertainment', 'Philosophy', 'Humanities', 'Languages, Literature and Cultural Mediation', 'Design and Management of Cultural Tourism', 'Education and Training Sciences', 'Sociology', 'History', 'History and Protection of Artistic and Musical Heritage' >

\section{A2. Postgraduate Education at UP}

The Postgraduate Education System at UP is subdivided as follows:

A) Annual Master's Degree Courses of First Level (Master di Primo Livello) The admission to these courses requires the possession of a Triennial University Degree and passing a selection exam. The courses are subdivided as follows:

Finance, Law and International relations

Finance, Business and Management: Industry specific fragrance in the cosmetic sector, European Integration: Community Policies and Design: International Business for small and medium enterprises, International finance and commerce),

\section{Scientific Innovation and Technology Transfer}

Strategic environmental management, Digital innovator in public administration and schools, Project Management \& Innovation Management, Surface Treatments for Industrial Applications,

The Mind and the Psycho-physical Well-being

Scientific and methodological bases of personal training, architecture and landscape psychology,

Preservation, Transmission of Culture and Training

Communication of the sciences, Death studies and the end of life for the interventions of support, Design of the tourist offer, TV screening techniques, intercultural studies, knowledge and practices for the reception of asylum seekers, Theories and techniques for the educational intervention aimed at the person suffering from a chronic pathology),

\section{Health, Environment and Territory}

Health care for ostomate and incontinent patients, Biostatistics for clinical research and scientific publication, Criminology: critical and social security, Deviance, institutions and psychosocial interactions, Diagnosis and surgical therapy of congenital heart disease, Director of urban security and combating violence, Pain and Pediatric Palliative Care, Basic and advanced Echocardiography, Basic and advanced Electrophysiology, Epidemiology and Community Knowledge, Management of skin lesions and difficult wounds (wound care), Governance of local development networks, Occupational and environmental hygiene, Specialist nurse in pathology and endoscopy of the digestive system, The pathologist's assistant: autopsy, histological and molecular techniques in pathological anatomy and forensic medicine, Rehabilitation of communication in auditory deficits, Clinical experimentation in oncology: clinical, managerial and operative aspects, Nurse case manager, The forensic nurse, Methodology of research in nutrition, Population nutrition, education and food safety, Patient safety in clinical practice, Prevention and emergency in mountain territory and high altitude, "Prosecco" wine, Organization and management of educational institutions in multicultural contexts).

\section{B) Biennial Master's Degrees Courses (Lauree Magistrali)}

The admission to these courses requires possession of the Triennal University Diploma and passing a selection exam. The courses are subdivided as follows.

\section{School of Agricultural Sciences and Veterinary:}

Biotechnology for nutrition, Food Sciences and Technologies, Animal Sciences and Technologies, Sciences and Technologies for Environment and Territory, Forestry and Environmental Sciences, Sustainable Agriculture, Viticulture, Enology and Wine Markets.

\section{School of Economy and Political Sciences:}

Business Administration, Economics and Law, Economics and Finance, European and Global Studies, Entrepreneurship and Innovation, European and Global Studies, Human rights and multi-level governance, Innovation and Social Service, 'International Relations and Diplomacy, Government Sciences and Public Policies.' 


\section{School of Engineering:}

Bioengineering, Environmental Engineering, ICT for Internet and Multimedia, Aerospace Engineering, Chemical Engineering and Industrial Processes, Civil Engineering, Materials Engineering, Automation Engineering, Electric Engineering, Product Innovation Engineering, Civil and Industrial Safety Engineering, Electronic Engineering, Energetic Engineering, Management Engineering, Computer Engineering, Mechanical Engineering, Mechatronics Engineering, Mathematical Engineering, Clinical Engineering.

School of Human and Social Sciences and Cultural Heritage:

Philosophy.

School for Healthcare: Medical Biotechnologies, Health Professions Sciences: Diagnostic Techniques, Sciences and Techniques of Preventive and Adapted Motorial Activity, Nursing and Obstetric Sciences, Rehabilitation Sciences of Health Professions.

School of Psychology:

Cognitive Neurosciences and Clinical Neuropsychology, Neurosciences and Neuropsychological Rehabilitation, Clinical Psychology, Clinical Psychology of Development, Clinical-dynamic Psychology, Applied Cognitive Psychology, Developmental Psychology and Education, Psychology of the Community, Promotion of Wellbeing and Social Change, Social psychology, Work and Communication, Clinical Psychology of Development.

\section{School of Science:}

Astronomy, Evolutionary Biology, Marine Biology, Health Biology, Industrial Bio-technologies, Chemistry, Industrial Chemistry, Data Science, Geology and Technical Geology, Computer Science, Mathematics, Molecular Biology, Physics, Data Physics, Materials Science, Natural Sciences, Statistical Sciences.

\section{School of Human and Social Sciences and Cultural Heritage:}

Cultures, Education and Global Society, Modern Philology: French and Italian Studies, Classic Letters and Ancient History, European and American Languages and Literatures, Modern languages for Communication and International Cooperation, Linguistics.

\section{C) Yearly Master's Degree Courses of Second Level (Master di Secondo Livello)}

The admission to these courses requires the possession of a Triennial University Degree and passing a selection exam. The courses are as follows.

Finance, Law and International Relations: 'International Business Lawyer', 'Innovation, planning and evaluation of policies and services'.

Scientific innovation and technology transfer: 'Building Information Modeling for Digitization of Assisted Planning', 'Forms of Contemporary Living', 'Planning, Design, Construction and Management of Airport Infrastructures'.

The mind and the psycho-physical well-being: 'Models and methodologies of intervention for Special Educational Needs (SEN)', 'Specific learning disorders and gifted children', 'Clinical neuropsychology', 'Psychology of the environment and longevity', 'Basic psychologist in the territory', 'Psychopathology of learning', 'Psychopathology and forensic neuropsychology', 'Developmental psychopathologies'.

\section{Preservation, Transmission of culture and Training}

'Conservation, management and enhancement of the industrial heritage', 'Inclusion and social innovation', 'Mediation as an operative tool within the family, criminal, community, civil and commercial fields', 'Evaluation, training and development of human resources'. 'Organizational analysis and interventions, risk prevention'.

\section{Health, Environment and Territory}

'Andrology and reproduction medicine', 'Advanced biostatistics for clinical research', 'Sport cardiology', 'Plastic aesthetic surgery', 'Pharmaco-epidemiology and integrated care assessment', 'Integrated risk management and health claims', 'Occupational and environmental hygiene', 'Specialist nurse in pathology and endoscopy of the digestive system', 'The pathologist's assistant: autoptic, histological and molecular techniques in pathological anatomy and forensic medicine', 'Rehabilitation of communication ability in hearing impairments', 'Clinical experimentation in oncology: aspects clinical, managerial and operative', 'Machine learning and big data in precision medicine and biomedical research', 'Pain therapy and Pediatric Palliative Care', 'Underwater and hyperbaric medicine', 'Lingual orthodontics', 'Cardiovascular pathology', Specialized pediatrics in pediatric cardiology', 'Pediatric gastroenterology', 'Neurology and clinical neurophysiology of the pediatric age', 'Pediatric rheumatology', 
'Pediatric onco-hematology', 'Pneumology and pediatric allergology', 'Hereditary metabolic diseases', 'Pediatric nephrology', 'Emergency pediatrics', 'Pituitary and adrenal diseases', 'Food quality and safety', 'Orthodontic sciences with straight arch technique', 'Advanced heart failure', 'Sedation and emergency in dentistry', 'Human Centered Project: the holistic treatment of the dental patient', 'Medically assisted procreation techniques and human reproduction sciences', 'Intensive care in cardiology'.

D) Single-cycle Master's Degree Courses (Lauree Magistrali a ciclo unico)

The admission to these courses requires possession of the State High School Diploma and passing a selection exam.

6-year Single Cycle Master's Degree Courses

School of Medicine: Medicine and Surgery, Dentistry and Dental Prosthesis.

5-year Single Cycle Master's Degree Courses

Law School: Law (it can be shared with the Paris 2 Panthéon-Assas University as a double Master's Course).

School of Healthcare: Chemistry and Pharmaceutical Technologies, Pharmacy.

School of Engineering: Civil Engineering - Architecture.

School of Psychology: Primary Education Sciences.

E) Post-master Higher Specialization Schools (Scuole di Specializzazione)

These Schools have Courses with a duration spanning from 5 to 2 years each, which are subdivided as follows:

Healthcare area for Physicians

5-year Courses: Allergology and Clinical Immunology, 'Anesthesia, reanimation, intensive care and pain', Cardiac Surgery, General Surgery, Pediatric Surgery, 'Plastic, reconstructive and aesthetic surgery', Emergency Medicine, Internal Medicine, Thoracic Surgery, Vascular Surgery, Neurosurgery, Medical Oncology, Orthopedics and Traumatology, Pediatrics, Urology.

4-year Courses: Pathological Anatomy, Audiology and Phoniatrics, Dermatology and Venereology, 'Hematology, Endocrinology and Metabolic diseases', Medical Genetics, Geriatrics, Gynecology and Obstetrics, Hygiene and preventive medicine, Diseases of the cardiovascular system, Diseases of the digestive tract, Diseases of the respiratory tract, Infectious and tropical diseases, Occupational medicine, Pathological anatomy, Audiology and phoniatrics, Legal Medicine.

Healthcare area for Non-physicians (4-year Courses)

Hospital pharmacy, Medical genetics, 'Microbiology and virology, Clinical pathology and clinical biochemistry.

Healthcare area for Non-physicians (3-year Courses)

Medical Physics, Pediatric dentistry, Orthodontics.

Area for Psychologists (5-year Courses):

Neuropsychology, Clinical psychology, Life cycle psychology.

Veterinary Area (3-year Courses)

Breeding, hygiene, pathology of aquatic species and control of derived products, Inspection of food of animal origin, Animal health, livestock breeding and livestock production.

Preservation of the Archaeological Heritage (2-year Course with the same denomination),

Preservation of the Historical and Artistic Heritage (2-year Course with the same denomination),

Legal Professions (2-year Course with the same denomination),

Evaluation and Management of Chemical Risk (2-year Course with the same denomination).

F) Doctoral Research Degree Courses

Macro-area 1: Mathematics, Physics \& Astronomy, Engineering, Information Sciences, Earth Sciences

Astronomy, Civil, Environmental and Architectural Engineering, Earth Sciences Fusion Science and Engineering, Industrial Engineering, Information Engineering, Management Engineering and Real Estate Economics, Mathematical Sciences, Mechatronics and Product Innovation Engineering, 
Molecular Sciences, Physics, Science \& Engineering of Materials and Nanostructures, Space Sciences,Technologies and Measurements, Statistical Science.

Macro-area 2: Life Sciences

Animal and Food Science, Biosciences, Crop Science, Psychological Sciences.

Macro-area 3: Human and Social Sciences

Economics and Management, Historical, Geographical, Anthropological Studies, History, Criticism and Preservation of Cultural Heritage, Human Rights, Society, and Multi-level Governance, International Law and Private and Labour Law, Law, Linguistic, Philological and Literary Sciences

Pedagogical, Educational and Instructional Sciences, Philosophy

Interdisciplinary Programs

Brain, Mind and Computer Science, Land, Environment, Resources and Health, Social Sciences: Interactions, Communication, Cultural Constructions

\section{A3. List of International Higher Education Institutions cooperating with UP}

The list of Higher Education Institutions all over the world, with which UP has established cooperation agreements in what refers to the international student mobility and joint research cooperation is the following:

\begin{tabular}{|c|c|}
\hline Albania & Universiteti i Mjekesise Tirane \\
\hline Algeria & Université M'hamed Bougara de Boumerdès \\
\hline Argentina & Pontificia Universidad Catolica Argentina \\
\hline Argentina & Universidad de Buenos Aires \\
\hline Arentina & Universidad Nacional de Cordoba \\
\hline Argentina & Universidad Nacional de Rio Negro \\
\hline Argentina & Universidad Nacional de San Martin \\
\hline Australia & University of New South Wales \\
\hline Australia & University of Sydney \\
\hline Bolivia & Universidad Mayor de San Andres (CIDES) \\
\hline Brazil & Pontificia Universidade Catolica do Parana' \\
\hline Brazil & Universidade de Caxias do Sul \\
\hline Brazil & Universidade de Passo Fundo \\
\hline Brazil & Universidade de Sao Paulo \\
\hline Brazil & Universidade do Vale do Rio dos Sinos UNISINOS \\
\hline Brazil & Universidade Estadual de Campinas \\
\hline Brazil & Universidade Federal da Paraiba \\
\hline Brazil & Universidade Federal de Minas Gerais \\
\hline Brazil & Universidade Federal de Santa Catarina \\
\hline Brazil & Universidade Federal do Estado da Bahia - UNEB \\
\hline Brazil & Universidade Federal do Estado do Rio de Janeiro \\
\hline Cameroun & Ecole Nationale Superieure des Travaux Publics de Yaounde \\
\hline Canada & Concordia University \\
\hline Canada & École de technologie supérieure de Montréal ÉTS \\
\hline Canada & Sir Sandford Fleming College \\
\hline Canada & Université de Montreal \\
\hline Canada & University of British Columbia \\
\hline
\end{tabular}




\begin{tabular}{|c|c|}
\hline Chile & Universidad Austral de Chile \\
\hline Chile & Universidad de Atacama \\
\hline Chile & Universidad de Chile \\
\hline China & China Pharmaceutical University \\
\hline China & Guangzhou University \\
\hline China & Jiangsu University \\
\hline China & Northwest University \\
\hline China & Renmin University - School of Philosophy \\
\hline China & $\begin{array}{l}\text { Shanghai Institute of Ceramics, Chinese Academy of Sciences } \\
\text { SICCAS }\end{array}$ \\
\hline China & ShanghaiTech University \\
\hline Colombia & Universidad del Rosario \\
\hline Colombia & Universidad del Rosario \\
\hline India & Datta Meghe Institute of Medical Sciences University \\
\hline Indonesia & Universitas Sumatera Utara \\
\hline Israel & University of Haifa \\
\hline Japan & Hokkaido University \\
\hline Japan & Kochi University \\
\hline Japan & Mie University \\
\hline Japan & Nagoya University \\
\hline Japan & Tokyo University of Agriculture and Technology \\
\hline Japan & Toyohashi University of Technology \\
\hline Japan & Waseda University \\
\hline Japan & Yokohama National University \\
\hline Kazakhstan & Kostanay State University named after A.Baitursynov \\
\hline Mexico & Corporación Mexicana de Investigación en Materiales COMIMSA \\
\hline Mexico & Universidad de Colima \\
\hline Mexico & Instituto Tecnologico de Saltillo \\
\hline Morocco & Université Internationale de Rabat \\
\hline Nepal & Tribhuvan University \\
\hline Paraguay & Universidad Nacional de Asuncion \\
\hline Russian Federation & Lomonosov Moscow State University \\
\hline Russian Federation & Magnitogorsk State Technical University \\
\hline Russian Federation & National Research University Higher School of Economics \\
\hline Russian Federation & National Research University Higher School of Economics \\
\hline Russian Federation & Novosibirsk State Technical University \\
\hline Russian federation & Tomsk State University \\
\hline Russian Federation & Samara State Technical University \\
\hline South Korea & Sogang University \\
\hline South Korea & Sungkyunkwan University \\
\hline
\end{tabular}




\begin{tabular}{|l|l|} 
South Korea & Seoul National University \\
\hline Taiwan & National Chiao Tung University \\
\hline Taiwas & National Tsing Hua University \\
\hline Tajikistan & Academy of Sciences of the Republic of Tajikistan \\
\hline USA & Boston University \\
\hline USA & Duke University \\
\hline USA & Harvard University, Harvard Medical School \\
\hline USA & San Diego State University \\
\hline USA & Texas A\&M University \\
\hline USA & University at Albany-SUNY \\
\hline USA & University of California, Davis \\
\hline USA & University of Michigan \\
\hline USA & Wake Forest University - School of Law \\
\hline USA & Old Dominion University \\
\cline { 1 - 2 } & \multicolumn{1}{|l}{} \\
\cline { 1 - 3 } &
\end{tabular}

